\title{
KONSEP PENGETAHUAN DASAR DALAM BELAJAR ALGORITMA UNTUK PEMULA
}

\author{
Oleh: Irma Suryani Bangun (0305201058) \\ Mahasiswa Prodi Pendidikan Matematika Fakultas Ilmu Tarbiyyah Dan Keguruan \\ Universitas Islam Negeri Sumatra Utara \\ Email: $\underline{\text { irma102001@gmail.com }}$
}

\begin{abstract}
ABSTRAK
Pesatnya perkembangan teknologi khususnya teknologi informatika tak bisa ditolak kehadiranya mereka yang menyelami perkembangannya tak bisa dilihat sebelah mata saja. Di samping itu, sebaliknya mereka yang tidak meyelami atau tidak mengikuti perkembangannya, maka akan mundur secara sukarela dalam tahap kompetensi dunia, dikarenakan dunia saat ini sangatlah familiar dengan teknologi computer ini. Sekarang, orang - orang yang memiliki lingkungan yang luas dan disenangi, serta dapat dijadikan lading berbiisisnis atau menghasilkan materi adalah dunia pemograman computer. Pada ruang lingkup pemograman computer terdapat ribuan macam bahasa pemograman yang disususn secara teratur oleh algoritma. "Algoritma adalah urutan langkah-langkah logis untuk memecahkan masalah yang disusun secara sistematis dan logis". Makna dari kata logis yang tertera diatas yakni sebagai kata kunci dalam algoritma. Step-step dalam penyusunan algoritma hendaknya memiliki penalaran logika yang tepat dan dapat diterntukan kebenarannya baik itu bersifat benar maupun salah. Pada beberapa masukan algoritma berarti step-step yang rinci yang dibuat untuk melakukan perbuatan tertentu. Peninjauan pada penentuan suatu algoritma yaitu, algoritma yang akan disusun harus benar. Maksudnya, algoritma akan memberikan masukan dari banykanya masukan yang ditentukan yang telah ditentukan. Adapun jika, seseorang memberikan masukan yang salah maka algoritma tersebut pasti tidak benar atau salah pula. Masalah seperti ini harus diperhatikan secara matang oleh para pemula untuk menghasilkan algoritma yang baik dan benar, namun minimnya pengetahuan dasar ilmu komputer khususnya dibidang algoritma menjadi tantangan tersendiri bagi pemula untuk memulainya.
\end{abstract}




\section{KATA KUNCI}

Konsep dasar, logis, langkah-langkah, algoritma, pemula

\section{PEMBAHASAN}

Komputer adalah alat elektronik yang bisa mendapatkan serta mengubah data menjadi informasi, menggerakan susuan yang tertata rapi dalam sebuah memori, serta dapat mengubah secara implusif dengan aturan -aturan tertentu. Sekarang telah banyak hal yang menggunakan alat aplikasi komputer, baik untuk membantu pekerjaan, untuk hiburan, untuk kebutuhan komersial, bahkan untuk ilmu pengetahuan. Aplikasi komputer yang digunakan tersebut, tentunya diinginkan bisa mengerjakan sesuatu dengan waktu yang singkat pada pengerjaan prosesnya. Untuk membuat psoses pengerjaan aplikasi yang memiliki waktu yang singkat, maka hendaknya orang membuat algoritma yang baik dalam memanjemen waktu atau sering disebut algoritma yang efisien. Efisien nya sebuah algoritma dilihat dari singkatnya waktu dalam penggunaan serta sedikitnya memori yang digunakan. Semakin kecil memori yang digunakan dan singkat waktu dalam pengerjaan maka semakin bagus algoritma yang disusun. Waktu dan ruang dalam pengerjaan algoritma sering pula disebut sebagai kompleksitas algoritma.

Agar diketahui perbandingan algoritma dengan algoritma lainnya maka dibutuhkan peninjauan terlebih dahulu. Peninjauan tersebut terlihat pada memori yang dibutuhkan dilihat dari struktur data yang digunakan, sedangkan perhitungan waktu yang dibutuhkan dilihat dari jumlah perintah atau operasi yang dijalankan. Penyesuaian fine - tuning secara manual, membutuhkan banyak waktu. Apalagi jikalau algoritma tersebut menghitung dan membandingkannya cukup panjang serta banyaknya jumlah perintah. Maka dari itu, dibutuhkan sebuah aplikasi yang membenatu menentukan kebutuhan pembangunan pada memilih algoritma yang lebih efisien untuk suatu aplikasi komputer.

Pesatnya perkembangan teknologi khususnya teknologi informatika tak bisa ditolak kehadiranya mereka yang menyelami perkembangannya tak bisa dilihat sebelah mata saja. Di samping itu, sebaliknya mereka yang tidak meyelami atau tidak mengikuti perkembangannya, maka akan mundur secara sukarela dalam tahap kompetensi dunia, dikarenakan dunia saat ini sangatlah familiar dengan teknologi computer ini. Bagaikan penyakit, teknolog computer ini telah merambah kesebagian besar aspek-aspek, seperti asepek keshidup[an manusia, aspek 
lingkungan manusia dan juga aspek kehidupan alam semesta. banyak yang menggunakan kecanggihan teknologi computer ini dmulai dari pemerintahan pusat hingga pemeritahan perdesaan, perusahaan, minimarket, supermarket, universitas, sekolah mengenengah baik kejuruan, menegah atas maupun menengah pertama, sampai ke selkolah dasar pun sudah tak asing lagi dengan kecanggihan teknologi ini. Sekarang, orang - orang yang memiliki lingkungan yang luas dan disenangi, serta dapat dijadikan lading berbiisisnis atau menghasilkan materi adalah dunia pemograman computer. Pada ruang lingkup pemograman computer terdapat ribuan macam bahasa pemograman yang disususn secara teratur oleh algoritma. Pada ruang lingkup pemrograman komputer berbagai banyak bahasa pemrograman. Seperti $\mathrm{C}++, \mathrm{C}$, basic, java pascal dan masih banyak lagi.

Ilmu teknologi atau sering juga disebut IT adalah sebuah ilmu yang mana kita ketahui bahwa massa ini teknologi menjadi pusat pembicaraan baik dari kalangan kecil ( anak - anak ) maupun kalangan besar ( dewasa ). Hal ini dikarenakan manfaatnya yang begitu besar di kalangan masyarakat nyata. Sekarang dan di masa depan, kehidupan di dunia ini tidak akan jauh dari teknologi. Pesatnya perkembangan teknologi memberi banyak ilmu yang trend bahwa sekarang semuanya dapat berjalan dengan lancer dan efektif . dalam aspek computer, bahkan taka sing lagi bagi kita semua dengan kata -kata hadware, software yang lumayan sering ditampilkan atau diajarkan pada bidang ini. Software yang sering disebut juga perangkat lunak adalah sebuah perangkat yang terbentuk dari susunan algoritma dan pemograman. Suatu aplikasi dapat dirancang apbila ada susunan - susunan algoritma dan pemograman yang membentuk rancangan aplikasi itu. Kecanggihan dalam pembentukan suatu rancangan aplikasi yang dinamis dan efektif baik dari segi tempat ( memori ) maupun waktu yang singkat maka perlu dilakukan ide yang baru dan pemikian yang kreatif sehingga dpat menghasilkan point yang lebih yang nantinya akan dipergunakan atau di manfaatkan oleh banayak orang.

Algoritma adalah komponen penting dari ilmu informatika atau ilmu computer, sebahagian besar ilmu informatika ataua ilmu computer mengarah ke pengertian algoritma. Akan tetapi, janganlah berasumsi bahwa algoritma melulu berkaitan dengan ilmu computer saja. Pada aspek sehari - hari ada banyak macam algoritma yang kita gunakan yang didskripsikan melalui langkah - langkah yang diisebut algoritma. Contohnya, seperti langkah dalam pembuatan masakan baik berupa makanan maupun minuman. Atau urutan - urutan yang dituangkan secara 
sistematis dalam sebuah resep/petunjuk tertentu, hal ini juga disebut dengan algoritma. Dalam sebuah petnjuk memasak, biasanya tertera step - step yang runut untuk digunakan dalam memasak . jika step yang dibuat tidak terjangkau logika atau tidak logis maka hidangan yang akan ditampilkan tidak dapat diprodiuksi atau hasil tidak memuaskan. Para ibu rumah tangga yang mencoba petunjuk dari buku atau media yang lainnya akan membaca satu per satu step step tersebut. Lalu kemudian melakukan susunan aturan tersebut sesuai dengan apa yang telah ia baca tadi. Nah, secara umum step by step yang dilakukan oleh ibu rumah tangga tersebut disebut algoritma sedangkan alat atau bahan yang digunakan disebut pemeroses ( processor).

\section{METODE PENELITIAN}

\section{Teori Tentang Algoritma}

Algoritma adalah langkah-langkah pemecahan masalah, sedangkan program adalah realisasi dari algoritma dalam bahasa pemrograman. Program ditulis dalam salah satu bahasa pemrograman dan kegiatan pembuatan program disebut pemrograman. Orang yang membuat program disebut programmer. Setiap langkah dalam program disebut pernyataan atau instruksi. Instruksi yang menjadi penghubung antara kode dan sistem bertanggung jawab untuk menyediakan informasi yang benar untuk dieksekusi.

\section{Mekanisme aplikasi algoritma}

Beberapa mekanisme yang digunakan dalam membuat dan merakit algoritma pada langkah pemrograman dibagi menjadi beberapa tahapan, antara lain:

a) Deklarasi variabel

b) Untuk mengetahui perlunya mendeklarasikan variabel dalam menggunakan bahasa pemrograman jika tidak semua bahasa pemrograman membutuhkannya.

c) Pemilihan tipe data Jika bahasa pemrograman yang akan digunakan memerlukan deklarasi variabel, ini harus diperhitungkan saat memilih tipe data.

Pertama; Penggunaan instruksi Beberapa instruksi memiliki kegunaan yang sama tetapi memiliki kelebihan dan kekurangan yang berbeda.

Kedua; Grammar Saat menulis program, kita terikat dengan grammar dari bahasa pemrograman yang akan digunakan.

ketiga; Menampilkan hasil Saat membuat algoritme, kami tidak memikirkan cara menampilkan hasilnya. Poin teknis ini diperhitungkan saat mengubahnya menjadi perangkat lunak. 
keempat; Operasikan penerjemah atau juru bahasa

Pada penulisan kali ini, digunakan metode untuk dapat menyelesaikannya hingga akhir metode yang di gunakan oleh penulis yakni studi literatur, yang meliputi studi pustaka dan internet searching. Yang dimaksud dengan studi pustaka yakni susunan perbuatan yang berkaitan erat pada data - data kepustakaan, yang mana akan dibaca, dicatat lalu diolah data tersebut secara baik dan benar. Danial dan Warsiah (2009:80) mengatakan, studi kepustakaan adalah penelitian yang dilakukan oleh peneliti dengan mengumpulkan sejumlah buku, majalah yang berkaitan dengan masalah dan tujuan penelitian. Sedangkan internet searching pencarian internet atau disebut juga pencarian online yakni pengumpulan data menggunakan media internet yang diproses melalui komputer maupun handphone, pengumpulan tersebut terhubung dengan server yang kemudian terhubung dengan internet yang telah tersebar di berbagai belahan dunia.

\section{HASIL DAN PEMBAHASAN}

Ditinjau dari awal mula kata algoritma itu kata ini memiliki masa lalu yang bisa dibilang unik. Manusia pada masa dulu hanya mendapati kata terserbut yang artinya proses berhitung menggunakan angka - angka arab. Orang - orang ahli algoritma apabila dapat menggunakan, menghitung serta mengaplikasikan angka arab tersebut. Para ahli bahasa mencoba mencari awal mula kata algoritma ini. Akan tetapi mereka mendapatkan tujuan yang kurang maksimal atau tidak memuaskan. Hingga pada akhirnya para matematikawan mendapatkan awal mula kata tersebut yang mana didapatkan dalam buku berbahasa arab yang dituliskam oleh ilmuan matematika Al-khawarizmi.

Nama lengkap beliau adalah Abu Ja'far Muhammad Bin Musa Al-Khuwarizmi. Kata AlKhawarizmi pada penggalan akhir dalam nama beliau dibaca algorism oleh orang - orang barat. Beliau menuliskan buku yang judulnya kitab Al Jabar Wal - Muqabalah dalam bahasa arab, atau the book of restoration and reducation dalam bahasa inggris, yang kemudian diterjemahkan dalam bahasa Indonesia menjadi buku penjumlahan dan penguran. Perubahan kata dari algorism menjadi algorithm muncul karena kata algorism sering dikelirukan dengan arithmetic, sehingga akhiran -sm berubah menjadi -thm. Karena perhitungan dengan angka Arab sudah menjadi hal yang biasa, maka lambat laun kata algorithm berangsur-angsur dipakai sebagai metode perhitungan (komputasi) secara umum, sehingga kehilangan makna kata aslinya. Dalam bahasa Indonesia, kata algorithm diserap menjadi algoritma. 


\section{Pengertian Algoritma}

Al-khawarizmi atau abu ja'far Muhammad bin musa al khawarizmi mengemukakan algoritma yaitu strategi khusus yang digunakan dalam memecahkan masalah.

Khunt dan stone mengemukakan bahwa algoritma yaitu seperangkat aturan yang secara benar menjelaskan rangkaan proses sedemikia rupa hingga segala peraturan tersebut efisien dan efektif dari segi urutan rangkaiannya.

Seymour Lipschutz, Ph.dan Marc Lipson,Ph.D, mengemukakan algoritma yakni data step by step terbatas dari instruks yang didefenisikan secara lengkap yang kemudian berguna untuk memecahkan masalah - masalah yang tak terduga.

Menurut Barakbah, algoritma erat kaitannya sama kata logis yakni kepekan orang untuk berfikir secara rasional mengenai sebuah masalah tertentu sehingga mewujudkan suatu hasil yang benar, terbukti dan bisa dicerna oleh akal fikiran, logis sering pula dikaitkan dengan kapasitas otak seseorang (kepintaran) orang yang dapat menalar dengan benar dan baik atau biasanya orang sebut dengan sebutan orang bijak atau orang pintar. Untuk memecahkan sebuah masalah akal fikiran sangatlah berperan penting didalamnya.

Telah dikatakan bahwa logis berkaitan dengan akal fikiran dan penalaran. Computer hanyalah sebuah prosesor untuk dapat mengesekusi sebuah instruksi saja, maka hendaknya kita menggunakan algoritma yang kemudia berfungsi untuk menunjukkan perintah yang baik dan benar. Algoritma dirancang dengan bahsa pemograman yang disebut program. Nah, dapat kita simpulkan bahwa pemograman yakni pelaksanaan atau penerapan dari suatu algortma yang kemudian diproses pada salah satu bahasa pemograman, lalu bisa dicerna oleh computer tersebut. Program yang dirancang oleh seseorang denagn salah satu bahasa pemograman disebut dengan programming ( pemograman ). Sedangkan seseorang yang merancang programming tersebut disebut programmer. Setiap tahapan dalam program dikatakan sebagi perintah, penyuluhan atau instruksi. Pada umumnya program - program ini terdiri dari berbagai macam perintah atau instruksi

Ketika sebuah instruksi dieksekusi, operasi yang sesuai dengan instruksi tersebut dilakukan oleh komputer. Pemograman juga dapat dikatakan sebgai tahapan penerapan step by step yang runut dalam memecahkan sebuah problem dengan menggunakan bahasa pemograman. Nah, setelah dijelaskan diatas maka di tarik sebuah pernyataan bahwa algoritma pemogrman adalah 
satu kesatuan kata yang mana mansudnya adalah step - step atau tahapan proses yang dilakukan dengan runut dalam memecahkan sebuah problem pemograman computer.

\section{Struktur algoritma}

Telah dijelaskan di paragraph sebelumnya bahwa lagoritma yakni runtutan yang masuk akal atau dapat dicerna dan diterma oleh fikiran yang dibentuk secara rapi diaman berguna dalam memecahkan masalah - masalah agar mengasilkan maksud tertentu. Pada kehidupan sehari-hari sadar maupun tidak kita telah meggunakan konsep algoritma. Akan tetapi apakah struktur algoritma yang sering kita gunakan sudah tepat ? untuk bisa menyelesaikan persoalan ini maka terdapat beberapa hal yang harus kita pahami terlebih dahulu tentang algoritma. Adapun struktur dasar algoritmma yakni sequence, selection dan repetition.

a) Sequence atau sering juga disebut sekuensial (runtutan) adalah struktur pertaman dalam membuat algoritma. Dalam struktur pertama ini berisikan step - step atau proses runut yang diawali menggunakan tahapan satu, dua, tiga, empat hingga selanjutnya. Sebuah program memeanglah dirancang untuk mengerjakan sebuah tahapan agar mencapai tujuan yang diinginkan.

b) Seceltion atau disebut juga struktur seleksi. Nah pada struktur ini menunjukkan pilhan tahapan - tahapan yang merjuk dalan memutuskan keptisan yang tepat. Selection juga biasanya dikenal sebaga struktur flowchart decision ( flowchart ini terbentuk seperti ketupat.

c) Repetition atau disebut pula dengan struktur pengulangan . dalam struktur ini sering juga kita mendapatkan sebuah instruksi atau aksi yang dikerjakan secara berulang - ulang. Misalnya apabila seseorang ingin menulis "memberi A" sebanyak sepuluh kali, maka hendaknya seseorang tersebut menggunakan struktur ni daripada harus menuliskannya berurut - urut sebanyak sepuluh kali.

\section{Konsep dasar algoritma}

Algoritma ialah rangkaian yang berurut yang dapat diterima akal fikiran dari pengambilan sebuah keputusan pada suatu masalah. Kata logis tak asing lagi dalam algoritma dan telah berulang kal di bahas pada bab sebelumnya, kata logis ini pula merupakan kata kunci yang 
wajib ada dalam pembuatan algoritma yang baik dan benar. Tahapan dalam pengerjaan algoritma hendaknya bersifat logis, artinya bisa ditentukan nilai kebenrannya baik itu bersifat benar maupun salah. Tahapan yang tidak benar menghasilkan perintah yang tidak benar pula atau salah. Nah untuk mengetahui lebih lanjut ada beberapa langkah dasar untuk menyusun algoritma diantarnya:

a) Menggunakan cara perumusan tahapan dalam menyelesaikan masalah melalui kata - kata atau kalimat yang terstruktur secara sistematis.

Misalnya: Dua buah mangkuk, diumpamakan mangkuk A diisi bubur sedangkan mangkuk B diisi susu. Masalah yang harus dipecahkan yakni bagaimana agar isi dari kedua mangkok tersebut dapat berpindah, buatlah algoritmanya

penyelesaian:

Langkah langkah

- Sediakan mangkuk kosong X

- Tuang bubur di mangkuk A ke mangkuk X

- Tuang susu di mangkuk B ke mangkuk A

- Tuang bubur di mangkuk X ke mangkuk B

- Selesai

b) Dengan menggabungkan kalimat dengan fragmen pernyataan dalam bahasa pemrograman (misalnya Pascal). Biasa disebut pseudo code (mirip dengan kode/perintah pemrograman).

Contoh: algoritma untuk konversi bilangan berbasis -10 menjadi bilangan berbasis -2

- INPUT a (a adalah bilangan berbasis 10)

Hit $=1$ (hit adalah indeks untuk menyiapkan sisa hasil bagi)

- DO WHILE a > 0

$\mathrm{sb}=$ sisa bagi a dangan 2

$\operatorname{bit}($ hit $)=s b$

hit $=$ hit +1

$\mathrm{a}=$ hasil pembagian dengan 2

ENDDO

- DO WHILE hit > 0

Cet bil(hit) 
Hit= hit +1

\section{ENDDO}

c) Menggunakan diagram alir (flowchart)

Indrajani mengemukkan pendapatnya bahwa flowchart ialah gambaran dengan menggukan grafik terhadap tahapan dan urutan proses suatu prosedur. Flowchart umumnya memodifikasikan masalah yang khusus untuk dapat dipelajari da dikoreksi lebih dalam

Flowchart dibagi menjadi 5 jenis flowchart, diantaranya adalah system flowchart, document flowchart, schematic flowchart, program flowchart, process flowchart. Berikut akan dijelaskan masing-masing jenis flowchart:

1. Flowchart sistem

System Flowchart atau disebut juga flowchart system yakni diagram alur yang memperlihatkan secara keseluruhan alur kerja system. System flowchart ini menggambaarkan tahapan proses yang tertera pada system. Diagram ini juga menampilkan apa - apa yang di lakukan oleh system.

2. Flowchart Document

Diagram alur dokumen atau document flowchart merupakan diagram alur formulir yang mana pada diagram ini akan di tunjukkan rangkaian laporan dokumen berserta salinan salinannya.

3. Schematic Flowchart

Schematic flowchart adalah flowchart yang serupa dengan flowchart system yakni menunjukan proses -proses dalam system, akan tetapi perbedaannya ialah flowchart ini mengguakan symbol dan gambar - gambar dari computer. Tujuan digunakannya gambar gambar adalah supaya komunikasi terhadap orang - orng yang tak mengerti symbol-sibol flowchart mudah paham. Pemakaian symbol ataupun gambar pada flowchart gampang dimengerti, namun dalam mengerjakannya lumayan sulit dan memakan waktu yang banyak dalam pengammbarannya

4. Program Flowchart

Program flowchart atau flowchart program adalah flowchart yang menggambarkan dengan sistematis tahapan -tahapan prosedur. Flowchart ini terbuat dari turunan flowchart system. Program flowchat terbagi menjadi dua bagian yakni flowchart logika pemograman dan flowchart program computer terperinci. Diagram alur logika atau flowchart program logika biasa 
dipakai untuk penggambaran setiap tahapan pada program computer dengan jelas dan logis. Diagram alur computer terperinci atau flowchart program computer terperinci biasanya dipakai utuk penggambaran perintah - perintah program ecara rinci. Perbedaan kedua bagian ini terletak pada penyiapan flowchartnya. Program flowchart logika disiapkan oleh system sedangkan flowchart program computer terperinci dsiapkan oleh programmer.

\section{Process Flowchart}

Bagan alir proses adalah bagan alir yang banyak digunakan dalam teknik industri. Bagan alir ini juga berguna bagi analis sistem untuk menggambarkan proses dalam suatu prosedur. Berikut ini adalah notasi atau simbol yang digunakan yang dapat dibagi menjadi 3 (tiga) kelompok, yaitu:

Flow Direction Symbols (Simbol Penghubung / flow) Simbol yang digunakan untuk menghubungkan antara satu simbol dengan simbol lainnya. Simbol ini juga disebut connecting line.

* Processing Symbols ( Simbol Proses ) yakni simbol yang menunjukkan jenis operasi pemrosesan dalam suatu proses/prosedur.

* Simbol Input / Output Simbol ( Simbol Input - output ) menunjukkan jenis peralatan yang digunakan sebagai media input atau output

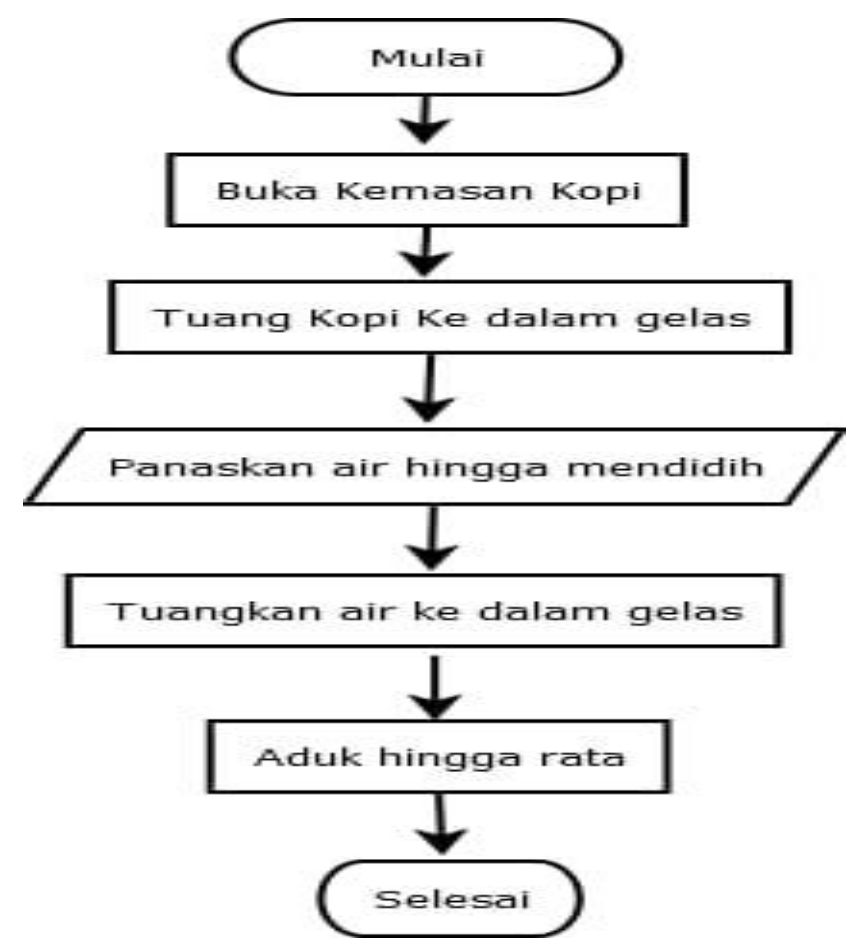

Gambar 1. Contoh flowchart sederhana dalam pembuatan kopi 
Tahapan dalam flowchart dibagi menjadi dua, yaitu:

Tahap pemecahan masalah adalah proses dari masalah tersebut sampai terbentuk suatu algoritma. Tahap implementasi adalah proses penerapan algoritma untuk menghasilkan solusi. Solusi yang dimaksud adalah program yang merupakan implementasi dari algoritma yang dikompilasi.

\section{Jenis - jenis algoritma}

a) Algoritma Membagi dan Menaklukkan

Algoritma membagi dan menaklukkan atau sering disebut juga dengan algoritma devide and conquer ialah algoritma untuk memecahkan sebuah problem menggunakan cara pembagian menjadi beberapa masalah - masalah kecil. Cara pembagiannya yakni problem utama dibagi menjadi sub bagian kecil, lalu setiap sub bagian menentukan akar masalah. Apabilah masalah malasah tersebut telah terpecahkan dan mendapatkan solusi penyelesaian yang baik dan benar, maka setiap sub bagian masalah tadi disatukan mejadi satu kesatuan kembali. Banyak orang orang yang menggunakan algoritma ini karena dianggap netral dan mudah dipahami.

b) Algoritma pengulangan ( rekursif )

Dilaporkan dari analytic step bahwa algoritma ini menyelesaiakan suatu maslah dengan cara menjadikannya sub maslah kemudian mencerminkan atau memanggil maslah tadi secara berulang - ulang sehingga maslah tersebut dapat teratasi atau setidkanya apbila tak teratasi dapat kembali ke keadaan awalnya.

c) Dynamic Programming Algorithm

Dynamic Programming Algorithm atau dapat diartikan sebagai algoritma pemograman yang dinamis ialah maniferstasi frasa “ melihat masa lalu dan membenarkan masa depan”. Nah pada frasa ini dijelaskan bahwa algortima jenis ini ialah algoritma yang menyelesaikan problemnya menggunakan cara penyelesaian subproblem yang lama. Hal ini dikarenakan maksud dari penyelesaian subproblem yang lama dapat berupa apa pun, maka dari itu Dynamic Programming Algorithm dikatakan sebgai algoritma pemograman yang dinamis atau tak stabil.

\section{d) Algoritma Serakah ( Greedy)}

Nah pada jenis selanjutnya yakni algoritma serakah atau algoritma greedy dikatkan serakah kartena algoritma ini memecahkan suatu maslah pada computer menggunakan penyelesaian yang bersifat universal dan jelas. Pada algoritma ini pula tidak ada pertimbangan dalam mengambil 
keputusan baik pertimbangan hasil sebelumnya maupun pertimbangan hasil yang akan datang. Algoritma ini berbanding terbaling dengan algoritma sebelumya yakni Dynamic Programming Algorithm

e) Algoritma Brute Force

Algoritma in yakni algoritma yang sangat dasar untuk mencari segala kemungkinan hingga mencapai tujuan atau maksud yang ingin diraih. Algoritma brute force ini juga merupakan suatu langkah yang masuk diakal dan mempertimbangkan bebagai macam pilihan secara maksimal, akan tetapi waktu yang di gunakan dalam algoritma jenis ini kurang efisien dikarenakan algoritma ini memakan waktu yang lama.

f) Algoritma Pelacakan Balik

Algoritma pelacak balik atau disebut juga backtracking adalah langkah algoritma yang memecahkan problemnya secara rekrusif, akan tetapu bedanya ialah ketika sebuah topic ta menyelesaikan problemnya maka lagoritma akan mendelete topic tersebut dan melangkah kebelakang untuk mengulangi penyelesaian masalah ini.

\section{Ciri algoritma yang baik}

Diantara ciri algoritma yang baik dan benar yang bisa digunakan yakni:

a) Sebuah algoritma hendaknya mempunyai perhitungan yang logis atau stretegi yang sesuai untuk memecahkan masalah yang ada.

b) Memanifestasikan output yang sesuai dengan waktu yang efisien dan memori yang efektif.

c) Algoritma dirancang menggunakan format yang gampang dimengerti dan gampang di aplikasikan pada bahasa pemograman yang lan

d) Algoritma dirancang menggunakn bahasa yang sederhana dan dijelaskan secara rinci serta tersusun secara sistematis sehingga tak memunculkan makna yang amigu ( makna ganda )

e) Segala aturan atau langkah - langkah yang digunakan harus terperinci secara jelas.

f) Segala tahapan dalam pengerjaan algoritma hendaknya memiliki awal dan memiliki akhir sesudah selesai mengoparsikan algoritma tersebut.

\section{Penyajian Dalam Algoritma}

Dal hal ini algoritma biasa disajikan kedalam dua bentuk yang dimana algoritma disajikan dalam bentuk teks dan juga algoritma disajikan kedalam bentuk simbol maupun gambar. Secara 
tertulis penyajian algoritma ini selalu menggunakan sebuah metode language stucture dan juga peudocode. Berbeda lagi dengan bentuk penyajian yang biasa menggunakan bentuk simbol ataupun gambar. Karna bentuk penyajian ini menggunakan sebuah flowchart, HIPO, dan berbagai hal lainnya yang berkaitan dengan gambar ataupun simbol.

a. Penyajian menggunakan tulisan : Penyajian menggunakan tulisan yaitu algoritma penyajian menggunakan tulisan terstruktur, contoh penyajian menggunakan tulisan yaitu pseudocode dan struktur bahasa

Kata Pseudo ini berarti tiruan sedangkan arti code sendiri adalah kode yang dimana setiap instruksi yang ditulis dengan menggunakan bahasa komputer atau kode bahasa pemrograman itu berhubungan dengan kode tersebut. Kalau kita mengartikan istilah ini secara bebas, maka dapat kita artikan bahwa pseudocode berarti sebuah tiruan ataupun sebuah tiruan yang berasal dari kode bahasa pemrograman itu sendiri. Intinya secara dasar, pengertian pseudocode ini sendiri adalah suatu bahasa yang akan akan membuat programmer itu sendiri memikirkan masalah apa yang akan dicari tau bagaimana cara memecahkannya walaupun tanpa harus memikirkan sintaks bahasa pemrograman tertentu. Dalam pseudocode tidak pernah ada aturan dalam penulisan sintaks. Oleh karna itu pseudocode ini selalu digunakan untuk menggambarkan suatu susunan yang logis dalam program yang berasal dari bahasa pemrograman.

Tidak hanya pseudocode ini saja, ternyata penyajian algoritma melalui tulisan juga dapat berupa struktur bahasa atau language structure berupa penyajian algoritma yang dilandasi pengstrukturan bahasa yang sering digunakan setiap hari dengan tidak melihat peraturan apa saja yang berlaku dalam algoritma tersebut.

Misal: algoritma memasak telur dadar

- Awal

- Menyaipkan: telur, minyak goreng, garam

- Menyaipkan alat: kompor, penggorengan, dll

- Panaskan minyak goreng di wajan

- Telur ceplok

- Jika telur sudah matang, lanjutkan ke langkah berikutnya jika telur belum matang, goreng telur hingga matang

- Angkat telur 
- $\quad$ Taruh di piring

- Selesai

Aturan Umum dalam Penulisan sebuah Teks Algoritma (Pseudocode)

> Judul algoritma: merupakan bagian yang dimana bagian ini terdiri dari nama algoritma dan deskripsi atau spesifikasi tentang algoritma tersebut. Penulisan nama ini sendiri harus pendek ataupun singkat serta menjelaskan apa saja yang diperbuat algoritma tersebut.

D Deklarasi: merupakan bagian yang dimana bagian ini berguna untuk mengartikan seluruh nama yang dipakai dalam program. Pada bagian nama ini dapat berupa nama konstanta, variabel, tipe, prosedur, dan fungsi.

> Description: merupakan bagian yang dimana bagian ini berguna untuk mengisikan berbagai uraian tentang semua langkah ataupun urutan dalam penyelesaian masalah yang dituliskan dalam sebuah notasi yang dimana hal ini akan dijelaskan pada contoh berikut.

Contohnya: algoritma _ kell _ lingkaran ( $<$ - judul algoritma). (menghitung luas dan keliling lingkaran untuk ukura jari - jari tertentu. Algoritma menerima masukkan jari - jari lingkaran, menghitung luas dan kelilingnya, dan mencetak luas lingkaran ke piranti keluaran < - ini spesifikasi algoritma)

Deklarasi:

Const phi $=3,14$

b) Penyajian menggunakan gambar/simbol

Dalam struktur bahasa Inggris diubah ke struktur bahasa Indonesia dijelaskan tahapantahapan pemecahan berbagai masalah dengan memakai bentuk kata-kata atau teks. Kelemahan dari metode ini adalah susunan urutan algoritmanya yang sangat dipengaruhi oleh semua cara penulisan tata bahasa penulisnya, oleh karna itu, terkadang sangat sulit bagi para pembaca untuk memahaminya. Maka dari alasan ini, dilakukan suau hal untuk mengembangkan suatu metode yang menggambarkan tahapan-tahapan pemecahan masalah dengan merepresentasikan simbolsimbol tertentu yang mudah dipahami, mudah digunakan, dan standar. Salah satu contohnya adalah diagram alir. Tujuan utama penggunaan flowchart atau presentasi menggunakan gambar/simbol adalah untuk menggambarkan suatu tahapan pemecahan masalah secara sederhana, terurai, rapi dan rapi. jelas menggunakan simbol standar. 


\section{KESIMPULAN}

Algoritma adalah komponen penting dari ilmu informatika atau ilmu computer, sebahagian besar ilmu informatika ataua ilmu computer mengarah ke pengertian algoritma. Akan tetapi, janganlah berasumsi bahwa algoritma melulu berkaitan dengan ilmu computer saja. Pada aspek sehari hari ada banyak macam algoritma yang kita gunakan yang didskripsikan melalui langkah langkah yang diisebut algoritma. Contohnya, seperti langkah dalam pembuatan masakan baik berupa makanan maupun minuman. Atau urutan - urutan yang dituangkan secara sistematis dalam sebuah resep/petunjuk tertentu, hal ini juga disebut dengan algoritma. Dalam sebuah petnjuk memasak, biasanya tertera step - step yang runut untuk digunakan dalam memasak . jika step yang dibuat tidak terjangkau logika atau tidak logis maka hidangan yang akan ditampilkan tidak dapat diprodiuksi atau hasil tidak memuaskan. Para ibu rumah tangga yang mencoba petunjuk dari buku atau media yang lainnya akan membaca satu per satu step -step tersebut. Lalu kemudian melakukan susunan aturan tersebut sesuai dengan apa yang telah ia baca tadi. Nah, secara umum step by step yang dilakukan oleh ibu rumah tangga tersebut disebut algoritma sedangkan alat atau bahan yang digunakan disebut pemeroses ( processor).

Adapun struktur dasar algoritmma yakni sequence, selection dan repetition.

1. Sequence atau sering juga disebut sekuensial (runtutan) adalah struktur pertaman dalam membuat algoritma. Dalam struktur pertama ini berisikan step - step atau proses runut yang diawali menggunakan tahapan satu, dua, tiga, empat hingga selanjutnya. Sebuah program memeanglah dirancang untuk mengerjakan sebuah tahapan agar mencapai tujuan yang diinginkan.

2. Seceltion atau disebut juga struktur seleksi. Nah pada struktur ini menunjukkan pilhan tahapan - tahapan yang merjuk dalan memutuskan keptisan yang tepat. Selection juga biasanya dikenal sebaga struktur flowchart decision ( flowchart ini terbentuk seperti ketupat.

3. Repetition atau disebut pula dengan struktur pengulangan . dalam struktur ini sering juga kita mendapatkan sebuah instruksi atau aksi yang dikerjakan secara berulang - ulang. Misalnya apabila seseorang ingin menulis "memberi A" sebanyak sepuluh kali, maka hendaknya seseorang tersebut menggunakan struktur ni daripada harus menuliskannya berurut - urut sebanyak sepuluh kali. 


\section{DAFTAR PUSTAKA}

Andy Hidayat Jatmika, dkk 2020. Pengenalan Logika dan Algoritma Pemrograman Menggunakan Program Aplikasi Komputer Scratch Bagi Siswa Usia Tingkat Dasar di SD Negeri Model Mataram. Jurnal pepadu. Vol 1. No 3. Jurnal online, http://jurnal.lppm.unram.ac.id/index.php/jurnalperpadu

Bagus, F Udayana, I Kadek. 2018. Penerapan Komponen dan Struktur Algoritma pada Algoritma dan Pemrograman Dasar. Jurnal Bisnis Dan Teknik Komputer, Politeknik NSC Surabaya. Vol 5 No.1.

Budiman, Edy. 2015. “Belajar Dasar Algoritma Dan Pemograman”. Samarinda.

https://amp.kompas.com/skola/read/2021/04/22/100000469/algoritma--definisi-ciri-jenisstruktur-dan-contohnya

H.S. Sumandi dan Agus Sumin. 1996. Algoritma Dan Pemograman Teknik Diagram Alur Dan Bahasa Basic Dasar. Gunadarma: Jakarta. Cet 6.

Isroqmi, Asnurul. 2017. Kemampuan Mahasiswa Memahami Logika Pemograman Computer Melalui Algoritma. Jurnal Pendidikan Matematika. Volume 2 No.2

Mahalisa, galih. 2020. Web Developer Informasi Berbasis Algoritma Pemograman. jurnal ilmiah tehcnologia. Vol 11 No 1.

Marga Retta, dkk. "Pengaruh Penerapan Algoritma terhadap Pembelajaran Pemrograman Komputer". Jurnal inovasi pendidikan matematika. Vol 2 No.2

Maulana, Gun, Gun. 2017 " Pembelajaran Dasar Algoritma dan Pemograman Menggunakan Elgoritma Berbasis Web ". Jurnal teknik mesin. Vol 6. No 7

Adryan Stepanus, dkk. 2017 “ Implementasi Algoritma Dijkstra Dalam Pencarian Rute Terpendek Tempat Wisata Di Kabupaten Gunung Kidul Dengan Program Visual Basic". Junal matematika, FMIPA. Vol 6. Jurnal online https://journal.unnes.ac.id/sju/index.php/ujm 